\title{
Municipal solid waste management in a new legislation: comprehensive approach
}

\author{
Maria Berezyuk ${ }^{1}$, Alena Rumyantseva ${ }^{1}$, and Alena Lapina ${ }^{1 \mathrm{a}}$ \\ ${ }^{1}$ Department of Environmental Economics, Ural Federal University, 620002, Yekaterinburg, Russia
}

\begin{abstract}
The problem of the municipal solid waste (MSW) formation and recycling has been very important for many decades in the Russian Federation. The sustainable development of the Russian Federation subjects and municipalities, their evolution to the status of "smart cities" is not possible without solving this problem. The current situation in the area of SHW treatment leads to the dangerous environmental pollution, improper use of the natural resources, and the significant economic damage and poses a threat to the health of the present and future generations of the country. The authors examine the issues of implementation of the changes in the field of municipal solid waste management legislation. The problems of the comprehensive waste management are also discussed on the example of the Sverdlovsk region (Sverdlovskaya Oblast).
\end{abstract}

\section{Municipal solid waste formation as a kind of negative impact on the environment}

The sustainable development of the modern society is a comprehensive result of the whole number of components. The environmental component becomes more and more critical with every year. For almost all subjects of the Russian Federation one of the main task in the field of environment protection is solving the problem of neutralization and reclamation of the waste, among which the biggest problem is the municipal solid waste generated in the residential area, due to the complex morphological structure and uneven distribution of the formation sources. The amount of the industrial and consumption waste generated in the Russian Federation is 5,168.3 mln t., the share of the used and neutralized waste was $45.6 \%$, i.e. $2,357.2 \mathrm{mlnt}$. in 2014 . For comparison, the amount of the generated solid municipal waste was equal to $56.68 \mathrm{mln}$ t. and the share of the used and neutralized waste was just $7.5 \%$ or $4.26 \mathrm{mln}$ t. The dynamics of the formation and use of the industrial and consumption waste and municipal solid waste in the Russian federation is shown on Figure 1, 2 [1].

\footnotetext{
${ }^{a}$ Corresponding author: alenalapi@yandex.ru
} 


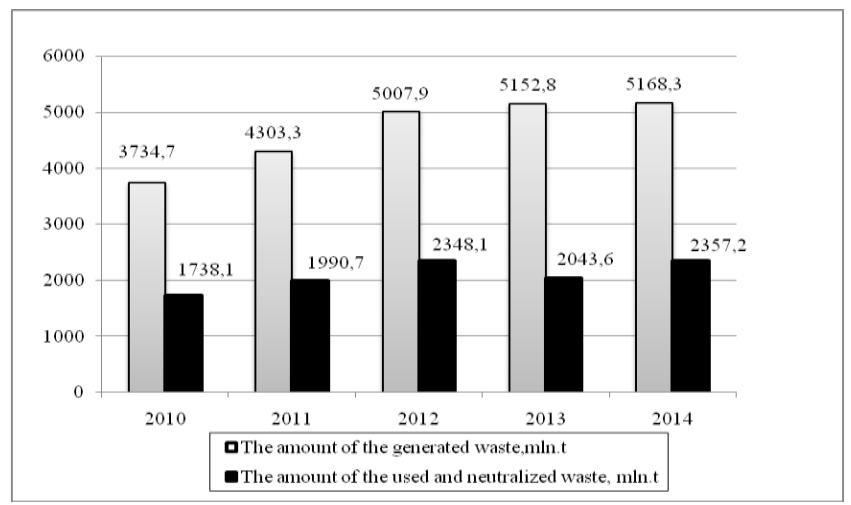

Fig. 1. The dynamics of the industrial and consumption waste generation and use in the Russian Federation.

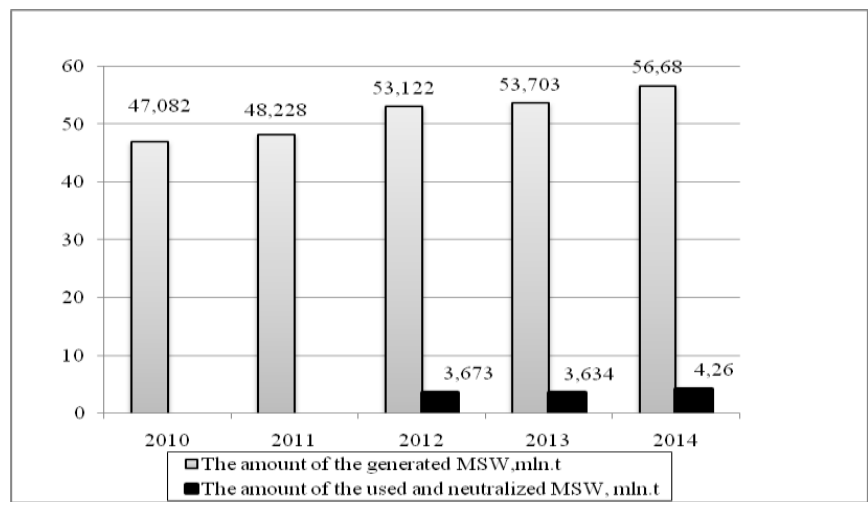

Fig. 2. The dynamics of the MSW generation and use in the Russian Federation.

The sanitary cleaning of the inhabited localities is one of the most complex and important challenges faced by the local municipal autonomous bodies at the territory of the Sverdlovsk region. At the same time the amount of the MSW is increasing and the territorial opportunities for its disposal are decreasing.

The data on the amount of the MSW generation in Sverdlovsk region in 2014 are presented in Table 1 [2].

Table 1. The amount of the MSW generation in Sverdlovsk region in 2014.

\begin{tabular}{|c|c|c|c|c|c|c|c|}
\hline \multirow[b]{2}{*}{ Index } & \multirow[b]{2}{*}{$\begin{array}{c}\text { Region in } \\
\text { total }\end{array}$} & \multicolumn{5}{|c|}{$\begin{array}{l}\text { The administrative district } \\
\text { of the Sverdlovsk region }\end{array}$} & \multirow{2}{*}{ 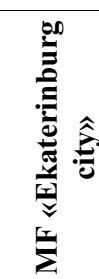 } \\
\hline & & 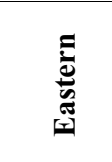 & 音 & 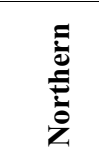 & 㐫 & $\begin{array}{l}5 \\
\vdots \\
0 \\
0\end{array}$ & \\
\hline $\begin{array}{l}\text { Municipal waste generation } \\
\text { amount, ths. t. }\end{array}$ & 1775.9 & 310.13 & 269.2 & 175.97 & 400.84 & 189.9 & 568. \\
\hline $\begin{array}{l}\text { including the solid municipal } \\
\text { waste }\end{array}$ & 1540.16 & 89.38 & 254.89 & 175.88 & 400.7 & 189.86 & 117.87 \\
\hline $\begin{array}{l}\text { actual municipal solid waste } \\
\text { generation per one resident } \\
\text { of the district, } \mathrm{t} / \mathrm{l} \text { resident }\end{array}$ & 0.36 & 0.18 & 0.41 & 0.37 & 0.58 & 0.32 & 0.083 \\
\hline
\end{tabular}


For 20144.013 business entities reported on municipal waste treatment using the Technical report form (3.973 entities in 2013), which accounts for $96.1 \%$ of the total amount of the reported entities [2].

The comparative analysis of the municipal waste treatment during 2013-2014 is not carried out due to the Federal waste classification catalogue (FWCC-2014) entering into force, in which the group of the municipal waste does not include the types of waste that earlier belonged to it. The data regarding the generation, use, neutralization, placement, and availability of the municipal waste by the end of 2014 are presented in Table 2.

Table 2. The data regarding the generation, use, neutralization, placement, and availability of the municipal waste by the end of 2014 [2].

\begin{tabular}{|c|c|c|}
\hline Index & ths. t. & $\%$ \\
\hline Generated, in total & 1775.9 & 100.0 \\
\hline among them: municipal solid waste & 1540.2 & 86.1 \\
\hline municipal liquid waste & 235.7 & 13.9 \\
\hline Used and neutralized by the business entities, in total & 200.5 & 100.0 \\
\hline among them: municipal solid waste & 198.9 & 99.2 \\
\hline municipal liquid waste & 1.6 & 0.8 \\
\hline Placed, considering the temporarily stored wasteB, in total & 1523.4 & 100.0 \\
\hline among them: municipal solid waste & 1289.7 & 84.6 \\
\hline municipal liquid waste & 233.7 & 15.3 \\
\hline Waste availability by the end of the year & 59768.5 & 100.0 \\
\hline $\begin{array}{l}\text { The amount of business entities reported on the municipal } \\
\text { waste }\end{array}$ & $\begin{array}{l}4013 \text { out } \\
\text { of } 4175\end{array}$ & \\
\hline
\end{tabular}

In the region there is an unfavorable situation with the organization and operation of the municipal waste dumps.

Out of 429 facilities accumulating municipal waste 284 (66.2\%) have no defined business entities operating the accumulation facilities; 229 (53.4\%) facilities have no hydrogeological conclusion; 262 (61.1\%) facilities have no formal documents for the land tenure, landownership. One of the basic requirements for the dumps operating the existence of the project - is fulfilled only by 55 waste disposal facilities (12.8\%).

\section{Legislation changes in the field of MSW treatment}

Over the past two years the environmental legislation of the RF has undergone major and dramatic changes. In December of 2014 the Federal Law No. 458 "On the Amendments of the Federal Law "On production and Consumption Waste", certain legislative acts of the Russian federation and the annulment of certain legislative acts (provisions of the legislative acts) of the Russian Federation" (here in after Federal law No. 458) was adopted. This document dramatically changes the system of the waste treatment affecting the fundamental concepts and principles of the environmental legislation. The changes affected practically all aspects of the waste treatment, opening the subjects regarding the ownershift of the waste, the licensing of the waste treatment activities, professional training of the persons admitted to the waste treatment, and many others. In addition, the terminology used in the field of waste treatment was also changed. The innovations affected the most often generated waste - municipal solid waste [3].

Municipal Solid Waste (MSW) is the waste generated in the living quarters during the consumption by the individual persons as well as the goods that lost their consumer properties during the process of their use by the individual persons in order to satisfy their personal and domestic demands. The waste generated in the process of the legal entities 
activity, independent businessmen activity and similar by the structure to those generated in the living quarters during the consumption by the individual persons (Art. 1 of the Federal Law No. 89).

On January $1^{\text {st }}, 2016$ the Federal Law No. 89 was supplemented by a whole chapter chapter V. 1 "Regulation of the activities in the field of the municipal solid waste treatment".

Thus, according to the changes, the regional operators will be appointed for the activities in accumulation, transportation, treatment, recycling, neutralizing, and disposal of the MSW at the territories of the Russian Federation subjects.

Regional operator for the MSW treatment is a legal entity, which is required to conclude a contract for providing services for the treatment of MSW with an owner of the MSW, which are generated and accumulated in the regional operator's zone of activity (Art. 1 of the Federal Law No. 89 of 24.06.1998 "On the Production and Consumption Waste").

The regional operators should carry out their activity in accordance with the regional program in the field of the waste treatment and territorial scheme of the waste treatment, the development and approval of which will be within the competence of the Russian Federation from January $1^{\text {st }}, 2016$.

In 2016, besides the fundamental changes in the environment legislation, the dramatic changes in the field of housing and communal services legislation are planned. Thus, instead the service "removal of the waste" a new municipal service is introduced, which will be called "municipal solid waste treatment". The introduction of the new service will entail the changes of the procedure of calculating the amount of payment for collection and disposal of the MSW. Currently the amount the amount of payment for the same service is determined in anticipation of $1 \mathrm{~m}^{2}$ of the total area occupied by the consumer premises. According to the changes in the Federal Law No. 89 the fee will be calculated on the bases of MSW accumulating norms per 1 person [4].

For the regional operator's service of treating the MSW the executive authorities of the Russian Federation subject will set a uniform rate and the operator's expenses on MSW treatment and recycling will not be considered. The regional operator will be required to conclude a contract for providing services with either managing board of the apartment buildings or with the premises owners directly.

Thus, all the contractual relations of the managing boards with the transporting organizations, landfills and other companies processing the living quarters waste must be closed before December 31, 2015, as from January $1^{\text {st }}, 2016$ the only allowable party in the relations associated with the MSW for the managing boards will be the regional operator - the unified organization, that will provide for the service for the MSW treatment and getting payment for that from the residents..

It is planned that the environmental tax funds will be used for the development of the industry.

The concept of "environmental tax" was introduced by the Federal law No. 458 starting from January $1^{\text {st }}, 2015$. The said payment relates to the non-tax revenues of the federal budget and must be paid by the manufacturers and the importers of the recyclable goods. The essence of the introduce changes is that manufacturers, the importers of the goods are required to provide for the recycling of the waste generated by their goods consumption and after these goods lose their consumer properties either by their own or by paying the environmental tax. The list of such goods, including the packaging, corresponding recycling standards, environmental tax rate for each group of the goods to be recycled after the loss of their consumer properties, and the procedure of the tax collection shall be established by the Russian Federation Government. 
The funds received by the federal budget as the environmental tax will be distributed via the realization of the state programs of the Russian Federation in the form of grants to the Russian Federation subjects in the following areas:

- co-financing of the regional programs in the field of waste treatment and regional waste treatment scheme;

- covering of the expenses on the collection, transportation, processing, and recycling of the waste generated by the use of the goods;

- covering of the deficit of the funds received as a payment from population for the public services for the MSW treatment;

- the execution of the engineering survey and preparation of the project documentation for the construction of the facilities used for the waste recycling, waste neutralizing facilities, and the equipping of such facilities.

The said grants from the federal budget will be given in the manner established by the Russian Federation Government in proportion to the population living at the territory of the Russian federation subject.

In June of 2015 a meeting was held with the participation of the Russian Federation Government to establish the limits of the non-tax payments for the businessmen and organizations, where it was decided to introduce a moratorium in respect of the non-tax payment of the businessmen and organizations till January $1^{\text {st }}$, 2019. According to the results of the meeting a report No. DM-P13-48 gr of 01.06.15 was prepared with the instructions of the Russian Federation Prime Minister D.A. Medvedev, including the task to set the standard of the utilization for all categories of goods at the rate of $0 \%$, excluding batteries, tires, paper, light bulbs as well as the groups of goods, which are already under utilization.

Since January $1^{\text {st }}, 2016$ the payers of the fee for the negative environmental impact (NEI) when placing MSW must have been the operators on MSW treatment, regional operators carrying out the placing of the MSW. Besides, the expenses on the NEI payment when placing the MSW must be considered while setting the rate for the MSW treatment operator, regional operator in the manner prescribed by the fundamentals of pricing in the field of MSW treatment. As we can see, the changes provided by the Federal Law No. 458 significantly limit the rights of the local autonomous bodies in the field of the waste treatment.

In the connection with the unfinished legislative base, in particular for the transition to the new system of MSW management, in December of 2015 the RF President signed the Federal Law No. 404 of 29.12.2015 "On Amending the Federal Law "On the Environment protection" and the Russian Federation Certain Legislative Acts". The Law No. 404 actually introduces a transitional period in respect of the municipal solid waste treatment till January $1^{\text {st }}, 2017$ (earlier the Law No. 458 provided for the introduction of the rules for the MSW treatment since January $\left.1^{\text {st }}, 2016\right)$. During the transitional period it is supposed to perform the selection of the regional MSW treatment operators and to introduce a new municipal service "MSW treatment". Until then the waste removal will be still carried out as the part of the housing service in the form of "MSW collection and removal".

However, the Law No. 404 did not cancel the effectiveness since January $1^{\text {st }}, 2016$ of the most part of the provisions of the Law No. 458. The terms "Municipal solid waste" and "MSW treatment" are now enshrined in law, a number of rules came into force, regulating the activity in the field of MSW treatment: it is provided for the creation of the regional operators at the territory of the RF subjects who will collect, transport, process, utilize, neutralize, and dispose the MSW; the peculiarities of the contract signing for the service MSW treatment, the types of activity and rates, that are to be regulated; the procedure of the rate state regulation, the peculiarities of the organization of the state 
control (supervision) in the field of the rates regulation; the term "waste accumulation" is corrected, which is now understood as a temporary wage storage (for a period of no longer than 11 months) with a view to its future use, neutralizing, placing, and transportation (earlier this period was 6 months); the other provisions regulating the MSW treatment activity are also provided for.

Thus, the most complicated tasks currently facing the Russian Federation subjects executive authorities are:

- to develop the territorial scheme of the waste treatment;

- to appoint the regional operators;

- to set the rate limit (the rates for the MSW processing, neutralization and disposal, and the uniform rate for the regional operator service of the MSW treatment);

- to approve the regional programs in the field of waste treatment;

- to sign the contracts;

- to fill up the deficit of the waste processing facilities.

The new waste treatment system (Figure 3 ) is similar to the modern regulation models in the field of heat supply, water supply and water drainage [3].

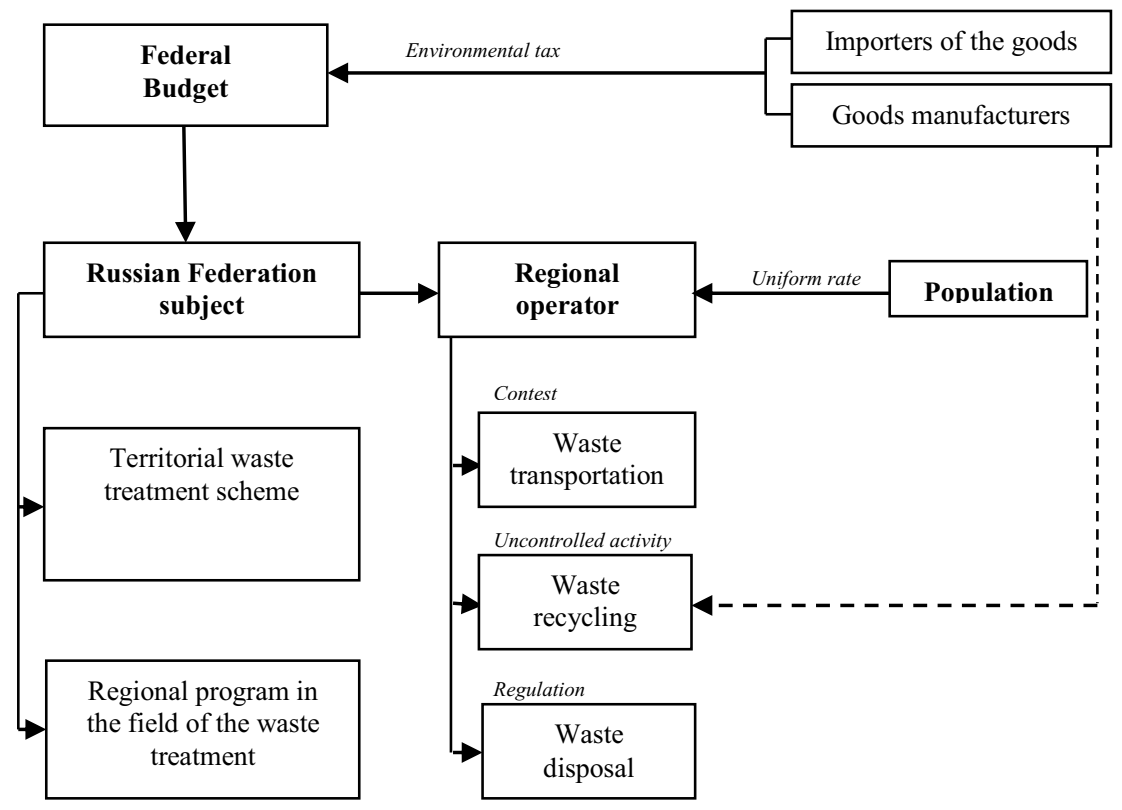

Fig. 3. New system of the waste treatment.

The acts of law of the Russian Federation subjects must regulate the relation connected with:

- the manner of development, coordination, and approval of the regional programs in the field of waste treatment;

- the content and procedure of the making agreement between the Russian Federation subjects executive authorities and the regional operators, as well as the conditions of the biddings for the carrying out the collection and transportation of the MSW;

- the procedure of the transfer to the local governments of the settlement or urban district of authority to establish the standards of the MSW accumulation (if necessary);

- the activity of the regional operators. 


\section{The main provisions of the integrated waste management system in the Sverdlovsk region}

Today at the territory of the Sverdlovsk region a difficult situation in the field of MSW treatment has arisen. The reforming of the MSW treatment activity and the selection of the optimal method of the waste utilization are the complex and multiple-factor task. The solving of this problem is based on the comprehensive approach. The comprehensive approach to the MSW management must consider economical, social, environmental, technical, and organizational aspects. All these aspects should be considered in combination, taking into account the specific conditions of each oblast (region). The waste integrated management (WIM) assumes that the approaches to the solving problem of MSW are selected depending on the specific local conditions and resources. While defining the aims of the MSW utilization program and planning the strategy it is advisable to have an idea about a certain WIM hierarchy. This hierarchy implies that first of all the measures for primary reduction of the waste should be considered, followed by the secondarily reduction: the reuse and recycling of the rest of the waste, and the last thing is the measures for utilization or disposal of the waste, generation of which could not be avoided and which are not recyclable.

In this regard, the following main principles of the waste integrated management can be emphasized:

1) MSW consists of various components, which should get the an individual approach;

2) all technologies and measures for MSW treatment should be developed in complex using their combination;

3) the territorial MSW treatment system should be developed considering the specificity of the local conditions and resources;

4) it is necessary to be based on a strategic long-term planning, which provides for the possibility to quickly and accurately consider the changes in MSW treatment, and to timely monitor and evaluate the results;

5) the participation of the municipals and all groups of population is necessary for the more effective solution of the MSW problems.

Considering the innovations in the MSW treatment system, the comprehensive approach to the waste management may be presented as following (Figure 4).

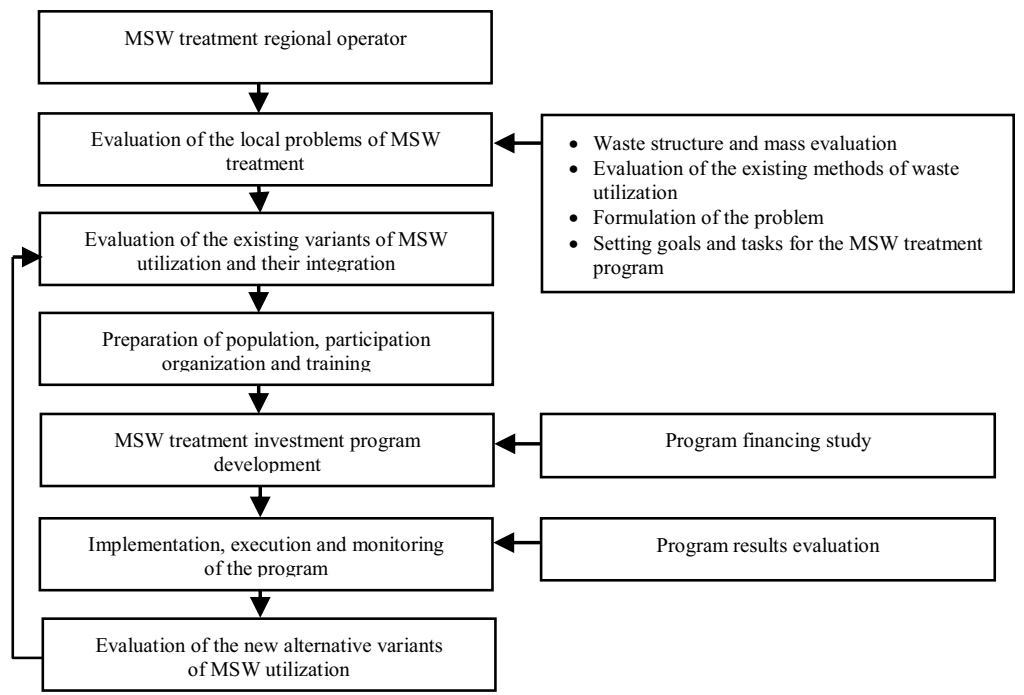

Fig. 4. The stages of the MSW integrated management. 
In the Sverdlovsk region they have already started developing the main mechanisms of the organization system of the municipal solid waste processing [5]. Back in September of 2015 the agreement between the Sverdlovsk region government and the state corporation was signed to establish a joint venture for the municipal solid waste treatment $(25 \%$ of its shares will belong to the Sverdlovsk region, the rest - to the company). The new structure will select the contractors working with waste both in general and on each technological stage. And this structure will accumulate the payments from population and organizations. The projects of modernization of the existing municipal MSW landfills and the construction of the new ones at the expense of the investors and coordination of their fulfillment by the attracted investors will be in the competence of the operator. The contests to select the investors are planned for 2016. The new organization will coordinate the work of all participants of this process: the managing boards collecting MSW, transporters, landfills owners and the others. The regional government expects that during several years at least 6 inter-municipal complexes will appear in the Middle Urals. The construction must start at the territory of the central industrial cluster of Sverdlovk region [5].

Amended and expanded by the authors SWOT-ANALYSIS of the scope of the municipal solid waste treatment at the territory of the Sverdlovsk region is given in Table 3 [6].

Table 3. SWOT-ANALUSIS of the scope of the municipal solid waste treatment at the territory of the Sverdlovsk region.

\begin{tabular}{|c|c|}
\hline Strengths (S) & Weaknesses (W) \\
\hline $\begin{array}{l}\text { 1. The business community's interest in the MSW } \\
\text { treatment sphere development. } \\
\text { 2. The presence of the companies recycling SMR. } \\
\text { 3. The interest of the regional authorities, executive } \\
\text { authorities of the Sverdlovk region, local } \\
\text { autonomous bodies and population in MSW } \\
\text { problem solution. } \\
\text { 4. The presence of the municipal and state } \\
\text { programs for the MSW treatment and preservation } \\
\text { of the environment. } \\
5 \text {. The executive authorities and local autonomous } \\
\text { bodies conduct measures aimed at the gradual } \\
\text { transition to the new form of management, which } \\
\text { will provide for the stable functioning } \\
\text { of the system in the field of MSW treatment. } \\
6 \text {. The presence of the ground areas for } \\
\text { the construction of the modern MSW landfills. } \\
7 \text {. The presence of the MSW processing innovative } \\
\text { technologies. } \\
\text { 8. The presence of the Sverdlovsk regional } \\
\text { cadastre of the industrial and consumption waste. }\end{array}$ & $\begin{array}{l}\text { 1. The low level of the environmental culture } \\
\text { of the population. } \\
\text { 2. The lack of logistical support of the MSW } \\
\text { collection and utilization process. } \\
\text { 3. The lack of the MSW landfills meeting } \\
\text { the requirements of the environmental and } \\
\text { sanitarian legislation. } \\
\text { 4. The absence of the civilized MSW collection } \\
\text { and utilization market. } \\
\text { 5. Failure to comply with the environmental } \\
\text { and sanitarian legislation while treating MSW. } \\
6 \text {. The absence of the centralized MSW } \\
\text { management authority in the region. } \\
\text { 7. Ineffective accounting system for MSW } \\
\text { generation, use, and utilization. } \\
\text { 8. Poor organization of the MSW collecting in } \\
\text { the rural communities and the private sector. } \\
\text { 9. The absence of the financial ability to } \\
\text { continue serving the sites by the managing } \\
\text { companies, as the money from the residents for } \\
\text { the "MSW treatment" service will be received } \\
\text { by the regional operator. } \\
\text { 10. The introduction of the transition period } \\
\text { due to the insufficient workup of the legislative } \\
\text { innovations. } \\
11 \text {. The payment of the environmental tax } \\
\text { is waived until January } 1 \text { st } 2019 \text {. }\end{array}$ \\
\hline Oppor & \\
\hline $\begin{array}{l}\text { 1. The development of the MSW and SMR } \\
\text { processing market. } \\
\text { 2. Attracting the population to MSW problem } \\
\text { solving. } \\
\text { 3. The MSW separate collection introduction and }\end{array}$ & $\begin{array}{l}\text { 1. The deterioration of the ecological and } \\
\text { sanitary-epidemiological status } \\
\text { of the territories: the air, soil, and ground } \\
\text { waters pollution. } \\
\text { 2. The existing problem of the MSW treatment }\end{array}$ \\
\hline
\end{tabular}


organization.

4. The introduction of the innovative technologies for the MSW processing (more environmentally friendly).

5. Improving the legal framework in the field of MSW treatment.

6. Environmental upbringing and education, starting from the kindergarten children, schoolchildren, students of the educational establishments to the specialists of the enterprises and organizations, as well as state and municipal authorities.

7. The development of the public-private partnership, the maximum involvement of the private investors in the MSW treatment system.

8. The improving of the rate regulation system for treating MSW

9. The creation of the unified MSW treatment system.

10. The MSW problem solving using the programtarget method.

11. The future availability of the information regarding the regulated activities in the field of MSW treatment.

SWOT-ANALYSIS allowed the emphasizing of the main problems in the field of MSW treatment at the territory of the Sverdlovsk region. The necessity to solve the said problems requires the perfection of the mechanisms and methods of the MSW treatment at the territory of the Sverdlovsk region.

The most important tool for the solving the posed tasks will be the comprehensive approach to the MSW treatment. To evaluate the effectiveness of this approach one may use the target indexes. The main target indexes characterizing the MSW treatment activity are presented in Table 4 [5].

Table 4. Target indexes of the waste integrated management in the Sverdlovsk region.

\begin{tabular}{|c|c|c|c|c|c|}
\hline \multirow{3}{*}{ Target index title } & \multicolumn{4}{|c|}{ The target indexes values, progressive total } & \multirow{3}{*}{$\begin{array}{l}\text { Basis value } \\
\text { of the target } \\
\text { index (at } \\
\text { the beginning } \\
\text { of the strategy } \\
\text { realization) } \\
2013\end{array}$} \\
\hline & \multirow{2}{*}{$\begin{array}{l}\text { Stage I } \\
(2013- \\
2016)\end{array}$} & \multicolumn{2}{|c|}{ Stage II } & \multirow{2}{*}{$\begin{array}{l}\text { Stage III } \\
(2025- \\
2030)\end{array}$} & \\
\hline & & $\begin{array}{c}2016- \\
2020\end{array}$ & $\begin{array}{l}2020- \\
2025\end{array}$ & & \\
\hline $\begin{array}{l}\text { The ratio of MSW processing to } \\
\text { the total volume of its generation per } \\
\text { year, } \%\end{array}$ & 15 & 35 & 55 & 80 & 12 \\
\hline $\begin{array}{l}\text { The share of the buried MSW in } \\
\text { the total generated volume, } \%\end{array}$ & 80 & 65 & 45 & 20 & 88 \\
\hline $\begin{array}{l}\text { The share of MSW, passing trough } \\
\text { the separate collection and assorting, } \\
\%\end{array}$ & 20 & 50 & 70 & 80 & 18 \\
\hline $\begin{array}{l}\text { The share of the secondary material } \\
\text { sources, extracted from the MSW } \\
\text { total volume, } \%\end{array}$ & 20 & 50 & 60 & - & 12 \\
\hline $\begin{array}{l}\text { The share of the landfills meeting } \\
\text { the requirements }\end{array}$ & 14 & 50 & 80 & 100 & 13 \\
\hline
\end{tabular}

leads to the social tension increase.

3. The overfill of the MSW landfills.

4. The emergencies in case of the MSW utilization technologies violation.

5. The negative effect of the selected

6. The double payment for the said municipal service by the most part of the working population.

7. The impossibility to transfer some specific types of the MSW. technologies introduction. 


\begin{tabular}{|l|c|c|c|c|c|}
\hline of the environmental legislation, \% & & & & & \\
\hline $\begin{array}{l}\text { The share of the abandoned illegal } \\
\text { dumps, \% }\end{array}$ & 70 & 100 & - & - & 68 \\
\hline $\begin{array}{l}\text { The share of the reclaimed objects for } \\
\text { the MSW disposal facilities, \% }\end{array}$ & 20 & 50 & 75 & 100 & 10 \\
\hline $\begin{array}{l}\text { The share of the stationary and } \\
\text { mobile reception points for } \\
\text { the secondary resources placed in } \\
\text { operation, \% }\end{array}$ & 35 & 60 & 100 & - & 34 \\
\hline $\begin{array}{l}\text { The share of the municipal } \\
\text { formations, at the territory of which } \\
\text { the sanitarian cleaning schemes were } \\
\text { developed, \% }\end{array}$ & 100 & - & - & - & 65 \\
\hline $\begin{array}{l}\text { The share of the MSW, used for } \\
\text { the energy production, \% }\end{array}$ & 5 & 5 & 10 & 30 & 0 \\
\hline
\end{tabular}

In conclusion it may be said that the realization of the waste integrated management in region is associated with the risk, which may impede the achievement of the set targets and results planned. Such risks may include: regulatory risks, macroeconomic risks, financial risks, organizational risks, social risks, natural risks, technical and innovation risks.

The measures of state regulation and management of the above risks able to minimize the consequences of the negative events and processes should include:

1) the creation of the effective control organization system for the Strategy fulfillment, as well as providing the stable development of the MSW treatment sphere at the existence of the said risks;

2) carrying out the planned checks of the nature resources using enterprises subject to the regional state environmental supervision;

3) annual monitoring of the environmental situation in the region;

4) the adoption of the normative legal acts, regulating the relations in the field of environmental protection and providing for ecological safety in the Sverdlovsk region.

Thus, WIM will allow the creation and providing for environmentally safe and economically effective system in the field of MSW treatment at the region territory.

\section{References}

1. State report "On the State and Environmental Protection of the Russian Federation in 2014", http://www.mnr.gov.ru/regulatory/list.php?part=1756

2. State report "On the Condition and Environment Protection in the Sverdlovsk Region in 2014", http://www.mprso.ru/gosudarstvennye-doklady-o-sostoyanii-i-ob-ohraneokruzhaiushei-sredy-sverdlovskoi-oblasti

3. O. Shaposhnikova, Ecologist's Reference-Book, 8 (4), 48-54 (2015)

4. M. Lamihova, Ecologist's Reference-Book, 5 (3), 12-19 (2015)

5. The Sverdlovsk Region Government official web-site. http://www.midural.ru/news/list/document70278/

6. The Municipal Solid Waste Treatment Integrated Strategy at the Territory of the Sverdlovsk region till 2030. http://energy.midural.ru/images/Upload/822/doctbo/1259-\%D0\%9F\%D0\%9F.pdf 